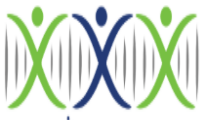

iRASD

Volume 9, Number 3, 2021, Pages 594-604

SCIENCES (PJHSS)

Journal Homepage:

https://journals. internationalrasd.org/index.php/pjhss

\title{
Challenges to Afghan Refugee Children's Education in Pakistan: A Human Security Perspective
}

\author{
Asifa Jahangir ${ }^{1}$, Furqan Khan ${ }^{2}$ \\ ${ }^{1}$ Centre for South Asian Studies, University of the Punjab, Lahore, Pakistan. Email: asifajahangir2327@gmail.com \\ 2 Department of International Relations, National Defence University, Islamabad, Pakistan. \\ Email: furqankhans66@gmail.com
}

\section{ARTICLE INFO}

\section{Article History:}

Received:

Revised:

Accepted:

November 19, 2021

Available Online: December 31, 2021

\section{Keywords:}

Refugee

Children

Education

Afghanistan

Pakistan
December 31, 2021

UNHCR

\section{ABSTRACT}

Human security is an essential component of the contemporary intra-state conflicts; promulgating renewed understanding of the perpetuating nature of the Afghan problem. Afghanistan, from the Soviet invasion to the US' long war, faces continued Human Security challenges, especially lack education in around 80 percent of school-aged children of Afghan refugees. Pakistan, which itself has the second largest number of school-aged children out of school, faces illiteracy in children of Afghan refugees as the surmountable challenge that links down to the seven broader components of human security identified by Mahbub-ul-Haq, Pakistan's former finance minister and economist, in the 1994 Human Development Report. The growing illiteracy in second and third-generation Afghan refugees is the product of poverty, socio-economic disparities, and socio-cultural restrictions, especially in regards to the relative discouragement of female education. In order to offset the gravity of challenges to the educational aspect of human security, the United Nations High Commissioner for Refugees (UNHCR) is continuously cooperating with the Pakistani government in enhancing educational infrastructure in terms of community and home-based schooling, vocational and technical training, and capacity building of Pakistan's schooling system to accommodate Afghan refugee children. Therefore, the paper takes qualitative checks of the primary sources from the government of Pakistan and UNHCR and secondary sources to find the answers to three following questions in different four parts of the paper. The result of this study is that the main challenge for Afghan refugee child education in Pakistan is the poor quality of education. Therefore, UNHCR should work with the Pakistani government to develop investment programs and put in place solid surveillance and oversight of schools to improve their quality to an acceptable standard.

(c) 2021 The Authors, Published by iRASD. This is an Open Access Article under the Creative Common Attribution Non-Commercial 4.0

Corresponding Author's Email: asifajahangir2327@gmail.com

\section{Introduction}

The term Afghan refugees denote the continued distress of the Afghan people who were caught in the crossfire of the Cold War between Americans and the Soviets since 1979. Direct violence, socio-economic disruption, and desire for survival forced a massive Afghan population to cross the Durand Line into geographically convenient Pakistan. In this situation, where Afghanistan was a nightmare for these refugees to return, Pakistan too, despite its welcoming environment, was not sufficient to ensure the fundamental requirements of their human security. For instance, fleeing Afghanistan protected them against direct violence and invasions under the aegis of national security but their socio-economic needs remain unfulfilled because of the insufficient provision of education to the children of Afghan Refugees.

Out of the 1.4 million registered Afghan refugees hosted by Pakistan over the past four decades, some 500, 000 are school-age children. A large chunk of these children is still unable 
to attend formal schooling for a variety of reasons including socio-economic and cultural factors, conservative attitude towards female education, lack of infrastructure, inconvenient curriculum, and the absence of an effective mechanism to deal with the uncertainty of refugees following the peaceful settlement of the Afghan conflict. Also, Pakistan falls short in meeting the required standard of education at home with the second-highest number of outof-school children in the world. This has consequently kept the Afghan refugee children away from quality education.

Apart from the initiatives launched by the Pakistani government, the United Nations High Commissioner for Refugees (UNHCR) is actively collaborating with the government to ensure the provision of quality education to Afghan refugee children. They have launched different programs such as Refugee Affected and Hosting Areas Program (RAHA), the regional Solutions Strategy for Afghan Refugees (SSAR), its educational activities at the Refugee Villages (RVs), and community-based schooling. Moreover, these activities are programmed to achieve vital objectives set by the UNHCR in its Global Education Strategy (2012-2016) and defined more specifically in its special Refugee Education Strategies for Pakistan.

Therefore, the chapter examines the overall educational provision to the children of Afghan refugees in the theoretical context of Human Security. This study investigates three following questions: (1) what are the details of collaborative projects of both UNHCR-Pakistan related to Afghan refugee children's education in Pakistan? (2) What actions have been taken by Pakistan for Afghan refugees in terms of assessing the status of mutual cooperation in combating illiteracy in children of Afghan refugees? (3) What challenges were ore are Afghan refugees facing in order to manage the education of Afghan refugees in general and children in particular? More specifically, if these challenges are categorized at national and provincial levels what are these?

To inquire these queries, the chapter is divided into three parts: first deals with the conceptual framework with reference to Afghan refugee influx to Pakistan as a result of different foreign invasions since 1979. It also explains the research methodology adopted in this research paper. The second portion looks at the collaboration between Pakistan and UNHCR for educating Afghan refugee children in particular, and Pakistan's actions for Afghan refugees in general. The third portion investigates the challenges to Afghan refugee children regarding education while residing within Pakistan. Also, this session briefly presents policy recommendations to improve access to quality education for children of Afghan refugees.

\section{Conceptual Framework of Human Security: Foreign Invasions of Afghanistan and Dilemma of Afghan Refugees}

Afghan refugees, since 1979, remain a protracted challenge and stark consequence of the overall Afghan conflict. Millions of refugees fled the country either because of the direct Soviet violence or indirectly forced by the deteriorating socio-economic conditions in multiple cycles over successive decades. Most of these displaced people took refuge in neighboring Pakistan and Iran following two important cycles of Soviet invasion in 1979 followed by the US invasion of 2001. Since then, Pakistan is hosting an ebb and flow of Afghan refugees depending upon the warring situation within the boundaries of Afghanistan. Out of a total of six million refugees, Pakistan, thanks to its open-door policy, hosted the largest share of around 4 million desperate Afghans with no basic facilities and financial backup. Initially, the refugees were settled in refugee camps and villages which were estimated at 350 by the late 1980s, and from where they were allowed to go in and out and open to work, earn and spend (Colville, 1997). With the passage of time especially during the 1990s, some refugees settled in rural and even urban centers with stable financial conditions while for others, the refugee camps became a permanent residence. According to the latest UNHCR (2020), Refugee Education Strategy for Pakistan (2020-2022), currently, there are only 32 percent of the protracted refugees live in 54 Refugee Villages (RVs) while the rest of 68 percent are scattered in major urban centers in the country (UNHCR, 2018a). The refugees are secure in terms of their lives and direct violence, yet, shelter from these national security threats failed to ensure the fundamental requirements of their human security.

\subsection{The concept of Human Security}

Human security emerged as the fundamental transition in the concept of security in post-Cold War politics, where the peaceful transition in the international system challenged the 
traditional rationalist concept of national security in light of national interests, presented by Hans Morgenthau. Invoking Einstein's "new manner of thinking", Dr. Mahbub-ul-Haq in his Human Development Report of 1994 called for a transition from nuclear security to human security (Mahbub-ul-Haq, 1994). This is because irrespective of their national security, "for most people, a feeling of insecurity arises more worries about daily life than from the dread of a cataclysmic world event' (Haq, 1994). Human security is fundamental but a complex manifestation of the term security in an individual human life which means "a child who did not die, a disease that did not spread, a job that was not cut, an ethnic tension that did not explode in violence, a dissident who was not silenced" (Haq, 1994).

The concept of human security is primarily understood in two different dimensions. Firstly, that individual, rather than the state is the ultimate object of security (Bretts \& Eagleton-Pierce, 2005). Mahbub-ul-Haq's innovative thinking forced the world to pay heed to the securitization of beings in terms of human security, which are indeed the building block of any society. The second is that the security of an individual is not necessarily coterminous with state or national security. For instance, a state that is secure as a physical entity can still host insecurities for its citizens. The post-Cold War politics are identified more by the intrastate conflicts than the inter-state rivalries, where states are secure but insecurity touchdown an individual's liberty, food, right to work, social security, health, and most importantly education.

\section{Research Methodology and Interview Technique}

In this research, a qualitative approach and inductive reasoning have been used to examine the subject area with a comprehensive outlook. Data is collected from primary and secondary sources and analyzed in order to decipher the concept of human security, the educational condition of Afghan refugee children within Pakistan, and highlight collaborative measures between UNHCR and Pakistan. The existing literature makes it easier to have a factual study. Interviews have been conducted to gain a deeper insight into the subject matter to fill up the research gaps related to collaboration between Pakistan and UNHCR. Additionally, inductive reasoning is used to examine qualitative data of interviews, which facilitates a comprehensive understanding of challenges faced by Pakistan to cope with this problem. This research article is analytical, exploratory, explanatory, and descriptive (Patton, 2002) as it attempts to gain an insight into the policy recommendations. Finally, a conclusion is drawn after vigorous analysis vis-à-vis anticipated goals of research by answering the research questions mentioned in the abstract.

To pursue this study, the interview method was used because of its utility of collecting large amounts of data quickly (Marshall \& Rossman, 1995). Interviews were open-ended for adjustments if additional queries should arise.

\subsection{Research Populations}

This research targets specific research participants (Creswell, 2009) including government officials, professors, experts; and practitioners as research respondents.

\subsection{Sample Size}

Research respondents have been selected using the purposive sampling technique due to their expediency (Bryman, 2008). The sample respondents' numbers are very limited (due to restricted time and their availability) as the format allows flexibility to the participants to focus on what is important to them regarding the topic of the paper.

\subsection{Data Collection}

For this study, the collection of data is done from primary as well as secondary sources. Primary data has been obtained mainly from the reports of UNHCR and UNICEF, the Pakistan Bureau of Statistics, and Pakistan's Constitution of 1973 along with interviews. In interviews, questions have been asked from the respondents to have details of collaborative measures between Pakistan and UNHCR, to identify challenges faced either by the UNHCR or Pakistan regarding Afghan refugee children's education within Pakistan, and suggest viable policy recommendations. Other facts-oriented data has been extracted from World Economic Forum, Global Competitive Index, Displacement Tracking Matrix, and Human Development report. Secondary sources include books, journal articles, and the internet. 


\section{Education of Afghan Refugee Children and Pakistan's Policy Actions}

Education basically opens new horizons of humans' survival in any society by securitizing them economically which is the fundamental element of humans' continued existence on this earth. Therefore, education is fundamental to individual human development and security. This is because illiteracy distances individuals from cherishing means and opportunities for progress and development. Afghan refugees in Pakistan, in addition to other social disparities, face a lack of education as a fundamental concern of human security.

After the horrible terrorist attack on Army Public School (APS) at Peshawar on 16 December 2014, a policy strategy named National Action Plan (NAP) was put forward, which determined the way for both government of Pakistan and armed forces how to cope with the rising wave of terrorism in Pakistan. Under this plan, many steps were taken and great achievements were made. According to research respondents, several actions have been undertaken. A few related to Afghan Refugee in Pakistan are as follows;

- The adoption of the National Comprehensive Policy on Voluntary Repatriation and Management of Afghan Refugees following 2015 by the Pakistani government introduces a new Visa Regime which accommodates, Afghan refugees of varying categories including students, vulnerable women, and other business and non-business individuals. This will allow the refugee children to continue their education in the country, get a job and even stay for long to become part of the society

- A special Proof of Registration (PoR) card with the help of the National Database and Registration Authority (NADRA) has been issued to the registered Afghan refugees which has a positive impact on the Afghan refugee privileges after the enactment of NAP. If any refuge has a card, police cannot arrest them but those refugees who don't have that card, police arrest them and send them to jail for 15 days, as reported by Ahmadullah during the interview.

- More importantly, its Operations Multi-Year Strategy (2015-2017) covers three important dimensions of refugees including 1) durable solution, 2) assistance and security, and 3) augmenting collaboration and partnership. These priorities address the interlinking domains such as education and vocational training to ensure sustainable empowerment of the refugee youth. The Strategy with its primary focus on education and vocational training to enhance socio-economic conditions of the refugees is consistent with the regional Solutions Strategy for Afghan Refugee (SSAR) Phase II (2015-2017). Moreover, the strategy also forms the foundation of UNHCR's Multi-Year Protection Strategy, the UNHCR-CCAR proposed jointly developed urban refugee policy and its draft livelihood strategy.

\subsection{Afghan Refugee Camps within Pakistan and their Education}

Initially, millions of Afghan refugees were accommodated on an ad hoc basis in refugee villages and camps. Educating Afghan refugee children was essential to protect them from social and political exploitations, and more to keep them at bay from militant activities. However, this was a challenge for the Pakistani government to provide elementary and primary education to Afghan children making around 44-50 percent of the total refugee population. This is because refugees were settled in less advanced areas where even the local children rarely get a proper education.

The Global Competitive Index (GCI) for the year 2016-2017 of the World Economic Forum ranks Pakistan at 110th among 138 countries in terms of policies in health care and primary education. The country, which hosts around 70 percent of the Afghan refugees, accounts for the second-highest figure in the world after Nigeria with 23 million out-of-school children as per UNICEF (World celebrate first International Day of Education, 2019). Moreover, in the country's latest budget-2020, Pakistan has allocated only around 2.7 percent of its GDP on education which is the lowest among all South Asian states. Resultantly, the country falls way short of meeting the 80 percent literacy target of the Millennium Development Goals (MDGs) with its 60 percent literacy rate in 2020 (UNICEF, 2019). In addition, Pakistan has only allocated around 2.7 percent and 7 percent of its GDP to education in the 2020 state budget, which is the lowest among all South Asian countries. As a result, with a literacy rate of 60 percent in 2020, the country is nowhere near the 80 percent illiteracy target of the Millennium Development Goals (MDGs) (Economic Survey (2020) shows Pakistan's literacy rate rose to 60 percent). Despite these factual challenges, which recognize education as a basic requirement 
for human security, Pakistan gives Afghan refugee children access to public and private educational institutions in the country.

Also, the commitment is more firmly rooted in the addition of article 25A of Pakistan's constitution as a result of the $18^{\text {th }}$ amendment in 2010 , which makes it obligatory for the state to provide "free and compulsory education to all children (regardless of nationality) of the age of five to sixteen year" (The Constitution of the Islamic Republic of Pakistan, 2020: 13). The amendment empowered provincial authorities with executive and legislative powers to take measures to accommodate registered and unregistered Afghan refugees in schools. This led to several pieces of legislation from provincial assemblies, including a bill for Islamabad in 2012 that provides that 'every child, regardless of gender, nationality or race, has a basic right to free and compulsory education in a neighborhood school' (An act to provide for free and compulsory education, 2012). This was followed by the National Refugee Legislation (NRL) in 2013 which protects the basic rights of the overall refugees in general and Afghan refugees in particular in the country. In 2017, Pakistan introduced the National Plan on Voluntary Repatriation and Management of Afghan Nationals to facilitate the voluntary return of the refugees (NPVRMAN).

Currently, there are 1.4 million registered Afghan refugees and 1 million undocumented refugees in temporary residence in Pakistan. Around 68 percent of the total Afghan refugees live in settled urban or peri-urban areas whereas the rest of the 32 percent reside in refugee camps and villages in different parts of the country (UNHCR, 2017a). Among them, children below 18 years of age make up around half or 47 percent of the population while 63 percent are young boys below 24 years of age. Educating such a huge number of Afghan refugees is complimentary not only to stability in Pakistan but also to building resourceful human capital for the peaceful future of Afghanistan. Apart from this, educating these refugees could serve Pakistan's interests as Islamabad can utilize this Afghan human capital as its ambassador within Afghanistan to build up a soft power narrative of Pakistan.

The UNHCR says in its reports that by May 2017, a total of 39 percent school going children between ages 5 to 8 were registered with the UNHCR in which its special mapping exercise of 2017 in refugee villages suggests that only 22 percent of children had access to primary education (UNHCR, 2017a). In Pakistan, Afghan refugees used several educational platforms for their children, from formal private and public schools to Afghan special schools and informal madrassas. According to a 2016 UNHCR report, around 25 percent of Afghan refugee children make up public schools, 21 percent choose private Pakistani schools, while the remaining 53 percent receive their formal education in Afghan special schools and madrasas. The greatest dependence and thus the higher proportion of Afghan special schools indicate the willingness of the refugees to raise their children in the light of Afghan values and traditions. In 2019, Maj. Gen. Asif Ghafoor, the former Inter-Services Public Relations (ISPR) spokesman for Pakistan, claimed that about 2.5 million students attend 30,000 madrasas across the country including the special Afghan madrassas (The Express Tribune, 2019).

Estimates suggest that around 500 to 600 madrassas were directly run by seven Mujahideen groups in the 1980s, where Afghan refugees' children were trained to fight the Soviet forces. (Herve, 2018: 11). However, the syllabus for religious schools under the NAP convened by Pakistan after the 2014 terrorist attack on Army Public School Peshawar has been modernized by adding Science and Technology, Computer, Mathematics, and English as compulsory subjects to meet modern challenges. Madrassas attract a huge number of refugee children because of religious conservatism and its cost-effective nature with free education, food, and shelter.

However, despite major flow-back of more than 60, 000 refugee back to Afghanistan between July 2016 and December 2017 (UNHCR, 2017b) and subsequently more than 30,000 between 1 January and 31 December 2018as per Displacement Tracking Matrix (DTM) (2019) and 6,220 between January and November 2019, yielding to international obligations and domestic legislations, the government is yet to ensure safe and standard education to the Afghan refugees. Lack of basic infrastructure and trained teachers, local burden, learning material, and low-quality education in government schools hinders the accommodation of such a huge number of Afghan refugee children. However, foreign aid and UN-affiliated agencies, 
notably the United Nations High Commissioner for Refugees (UNHCR) have been supporting Islamabad in its effort to eradicate illiteracy in protracted Afghan refugees.

Figure 1: School Enrolment (\%): Children of repatriating families that attended school in Pakistan

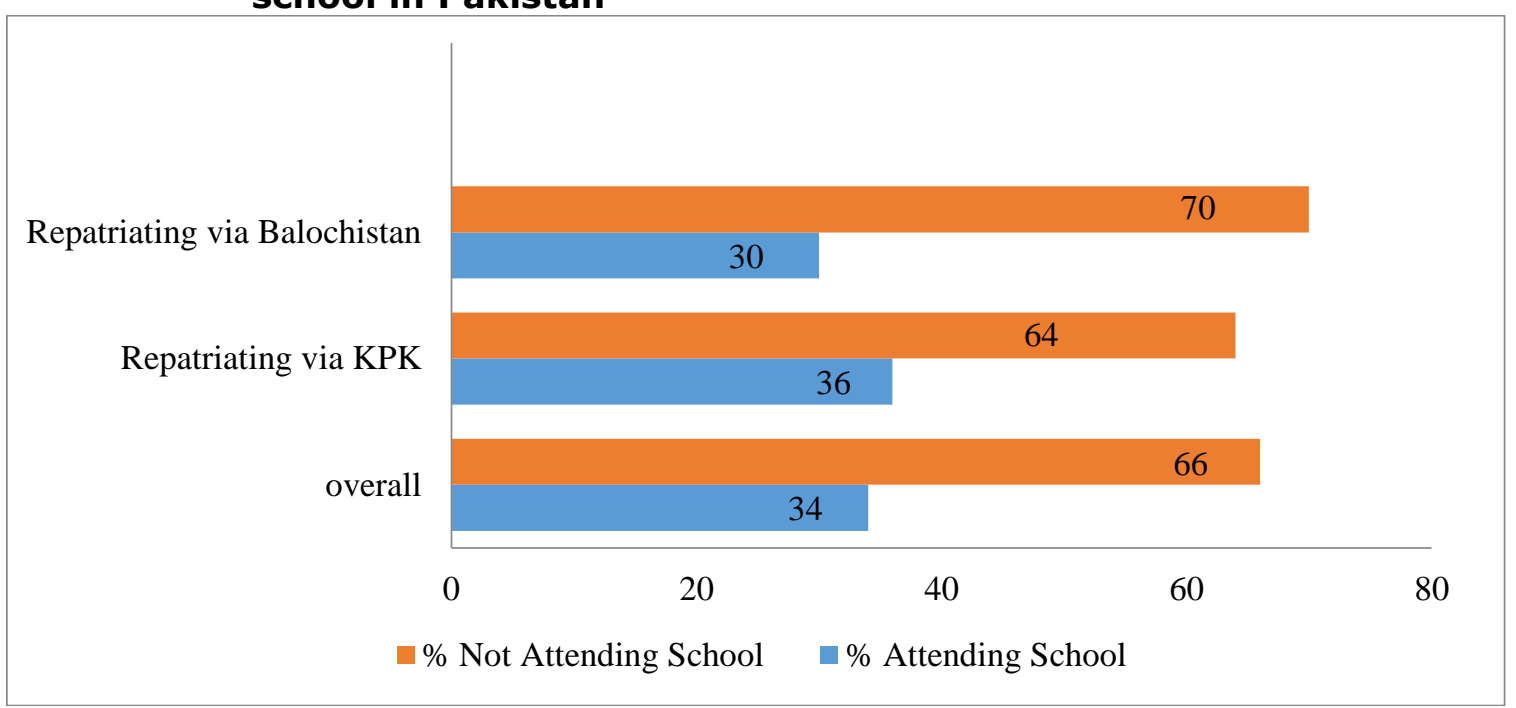

Source: UNHCR Report of 2017 (available at https://data2.unhcr.org/en/documents/download/73153

The chat data collected by the UNHCR from January to November 2019 on the voluntary return of Afghan refugees suggests that of the 20 percent of refugees remaining in Pakistan, around 5 percent stayed for educational purposes only. This corresponds to the small number of refugee children attending schools in Pakistan. The figure shows, for example, that of all refugee children living in Pakistan, only an average of 34 percent were able to attend school and a large majority of 6 percent were unable to attend school for various reasons.

\subsection{Pak-UNHCR Collaboration in Educating Afghan Refugee Children}

The UNHCR Global Education Strategy (2012-2016) envisions to 1) increases access to quality primary education, 2) expand access to secondary education, 3) provide safe learning environment, 4) provide long-term learning opportunities and, 5) meet different educational challenges (UNHCR, 2018a). UNHCR considers education as the inevitable pillar to achieve human security which ensures human rights, encourages intercultural dialogues, and promotes sustainable peace and development. For the last four decades in Pakistan, the UNHCR has assisted the Pakistani government in training teachers, providing textbooks and other school material, and renewed curricula so as to redefine the purpose of education in Pakistan. More specifically, its Refugee Education Strategy of 2016-2018 highlights its objectives vis-à-vis Afghan refugees in Pakistan. This strategy is consistent with the objectives of the UNHCR Global Education Strategy of 2012-2016 and seeks to;

- Ensure access to quality primary education to refugee children, especially female education.

- Improve the quality of primary and basic learning achievements.

- Encourage and assist refugee youth by providing them with technical skills and vocational training.

- Keep a check on refugee education and recommend policy changes to the host government.

With these objectives in hand, the UNHCR is involved in multiple initiatives and short and long-term programs to facilitate the Pakistani government in educating millions of Afghan refugee children. These education programs are mostly concentrated in around 54 refugee villages (RVs) across the country.

The UN sister agency UNESCO adopted its Education Strategy (2014-2021) in the year 2014 whose objectives are consistent with the major educational objectives of the UNHCR as detailed in its different strategies and initiatives. Both, UNICEF and UNESCO partnership can bring donors, influence provincial and federal budgets to expand educational opportunities enhance its quality and access for the protracted Afghan refugees. Hence, in this context, close 
partnership with UNICEF and UNESCO offers ample opportunity to the UNHCR to organize joint ventures and help achieve the Sustainable Development Goal - 4 by allowing children access to quality education (UNHCR, 2018a).

The Refugee Affected and Hosting Areas Program (RAHA) was launched in 2009 by the Pakistani government as a joint initiative with a number of ministries, NGOs and UN-affiliated organizations, including UNHCR, to improve social cohesion and coexistence in Pakistan. This was in line with the government's 2017 Voluntary Return Policy for Afghan Refugees, which aims to assist Afghan refugees during their stay in Pakistan. In addition, RAHA combines the individual humanitarian programs with large development initiatives to improve the educational infrastructure for Afghan refugees. RAHA successfully implements around 144 education-related projects from which around 11,500 refugee students and other employees benefit. At the opening ceremony of Global Education Monitoring (GEM) in Islamabad in 2019, UNHCR representative Ruvendrini Menikdivela stated that as part of the RAHA projects, his organization is improving the educational infrastructure in refugee villages in order to ensure safe and free access to education for the children of Afghan refugees to guarantee. RAHA is a unique initiative that provides a well-organized and workable platform to provide support and resources not only to refugees, but also to the local population, which will lead them to peaceful coexistence and social cohesion (UNHCR, 2018a).

The regional Solutions Strategy for Afghan Refugees (SSAR) of the UNHCR was launched in 2011 as the quadripartite arrangement with Pakistan, Iran, and Afghanistan to identify and solve the problems of Afghan refugees in their host countries (UNHCR, 2018b). It enables UNHCR to work with Pakistan to facilitate voluntary repatriation, build Afghan refugee capital to boost their sustainable reintegration, and finally, to preserve the basic rights of refugees in host countries.

In the UNHCR Education Strategy 2020-2022, it is estimated that in the past four decades, the UNHCR facilitated around 146 schools in 54Refugee Villages (RVs) in urban and rural areas (UNHCR Pakistan, 2020). These include 103 schools in Khyber Pakhtunkhwa, 35 in Balochistan and 8 in Punjab Province. In total, its educational programs have benefited around 56,000 refugee children and provided salaries to around 1,319 teachers and other staff. In addition, the UNHCR cooperates with the Albert Einstein German Academic Refugee Initiative Program (DAFI) to support Afghan students with access to higher education in Pakistan. In 2019 around 419 students benefited from this initiative, which is expected to grow in size in the coming years (UNHCR Pakistan, 2020).

\section{Challenges in Educating Afghan Refugee Children}

In Pakistan, the UNHCR points out in its latest report that currently only 32 percent of Afghan refugees live in 54 refugee villages across the country, while 68 percent live in (semi-) urban settlements (Mapping of Education Facilities and Refugee Enrollment, 2017: 7).

\subsection{No data compilation related to Afghans' Influx into Pakistan after 9/11}

Pakistan is the second country after Turkey where more than 2 million registered and half a million unregistered refugees live, mostly Afghans where 1.4 million refugees were registered with the UNHCR, almost 0.9 million were with the Pakistani National Database and Registration Authority (NADRA.) And the Afghan Embassy in Pakistan (Ahmad Ullah, 2020). A similar point of view was taken by a professor at the University of Peshawar who said that Pakistan has seen many Afghans moving in, the number fluctuating between 3-4 million, because many have been left undocumented over the years - around 1 million. According to the October 2019 update on voluntary repatriation from Pakistan, around 4,379,709 Afghan refugees have returned with the help of UNHCR since 2002. However, "the Afghan Commission rate is critical of this figure as it believes that many are recyclers who have not been documented or internal movement within the country has also at times made it difficult to register and document all the Afghans residing in Pakistan" (Prof. Dr. Nasreen Ghufran, 2020). In short, no data has been compiled or released by the Pakistani authorities showing how many Afghan refugees immigrated to Pakistan after September 11, 2001 following the U.S. invasion of Afghanistan. 


\subsection{Specific Policy of Afghan Refugees and Education of Their Children}

Many hundreds of thousands of Afghan refugees live in Pakistan, with 1.4 million registered since 1979. Pakistan has not been able to develop specific policies for Afghans living on its soil in the past four decades. In addition, under the NAP, Pakistan has taken several measures to remedy the evils directly or indirectly related to terrorism and the Afghan settlements in the country. However, Pakistan has not formulated a policy to educate Afghan refugee children, while UNHCR and Afghan Refugees Committees (Shoros) have set up schools for Afghan refugee children, an official said under conditions of anonymity. Another participant said that despite various attempts to deal with the remaining Afghan population in Pakistan, Pakistan does not have a clear refugee policy. UNHCR plays a key role in the education of Afghan children. Data on refugee education are rare (Prof. Dr. Nasreen Ghufran, 2020).

\subsection{Establishment of Schools}

According to the Ministry of States and Border Regions (SAFRON), 32 percent of refugees live in camps and 68 percent in cities, villages, etc. It is difficult for the Pakistani government to set up schools for them as they do not live in specific accommodation areas (Ahmad Ullah, 2020). In addition, the insufficient number of schools for around 500,000 refugee children is a major challenge that needs to be carefully examined by the UNHCR and the Pakistani government. These refugee children are growing by 50,000 to 60,000 per year, and their educational needs and needs are increasing accordingly (UNHCR, 2018a).

\subsection{No Allocation of Education in Pakistan's Budget for Afghan Refugee Children}

According to Alif-Ilan (a non-governmental organization) in Pakistan, nearly 25 million children are out of school. Viewed holistically, the educational allocation in the budgets at the federal and provisional level was very low. As a result, that factor also affects the education of Afghan refugee children, as Ahmadullah, a journalist at Mashaal Radio, said "I don't believe the federal or provincial government allocates budgets for the education of Afghan refugee children" (Ahmadullah, 2020) Therefore, the United Nations and its sister organizations, as well as other international NGOs, have been the main source of funding for the education of Afghan refugee children. Another participant from Peshawar University took a similar point of view. "Many international NGOs besides the UNHCR are interested in facilitating the education of Afghans" (Prof. Dr. Nasreen Ghufran, 2020). Ahmadullah went on to say that the former president of the Afghan School Association, Noor Habib Habib, told him in the interview that an NGO based in Germany had helped them with education.

\subsection{Demand of Birth Certificate by Government or Private Schools}

Another major challenge for Afghan children in further access to schools is that if Afghan children want to be admitted to state or private schools, the school authorities require a birth certificate or Form B, which they do not have. Therefore, with the help of Pakistani authorities, the Afghan community and international donor organizations, special Afghan schools have been set up in Afghan camps or villages. 6. Resettlement of Afghan Refugees from Rural Areas to Urban Centers: The resettlement of most Afghan refugees from refugee villages in rural areas to urban centers poses a challenge to the education of refugee children. This is because the UNHCR has difficulties in addressing these dispersed refugees especially in remote areas with a lack of basic educational infrastructure.

\subsection{Education is Responsibility of Provinces after $18^{\text {th }}$ Amendment in Pakistan's Constitution of 1973}

The devolution of educational powers into provincial levels as a result of the 18th amendment hinders UNHCR from uniformly continuing its educational programs across the country. This kind of decentralization complicates the process for the UNHCR as it has to deal with different provincial governments with varying policies, administrations and level of development (UNHCR, 2018a).

\subsection{Protracted Afghan Refugees across Pakistan}

The devolution of educational powers into provincial levels as a result of the 18th amendment hinders UNHCR from uniformly continuing its educational programs across the country. This kind of decentralization complicates the process for the UNHCR as it has to deal with different provincial governments with varying policies, administrations, and levels of development (Prof. Dr. Nasreen Ghufran, 2020). 


\subsection{Lack of Resources and Facilities in arduous Situation of COVID-19}

The major challenge is the lack of resources and facilities in Pakistan that are insufficient for its own population. 'Since the Pakistani government is politically and economically weak and is now affected by COVID-19, it has too much to do for its own population; the management of the refugees in the current situation itself is a great challenge' (Prof. Dr. Nasreen Ghufran, 2020). However, Pakistan has released around 1.551 billion Pakistani rupees to its Higher Education Commission (HEC) to allow Afghan university students to stay in Pakistan and continue their studies amid COVID-19 (According to Arab News Pakistan (2020) Pakistan releases Rs. 1.5 billion in grant for Afghan university students), What is still missing, however, is a long-term program to support continuing Afghan refugees with training in Pakistani facilities.

\subsection{Underlying Factors for absence of Afghan Refugee Children in Schools}

Economic and socio-cultural factors are primarily responsible for the lack of school attendance by Afghan refugee children. The PoR card only protects Afghan refugees from being rejected without economic and social security. As a result, the refugees mostly work on the underpaid black markets and do not send their children to school, but are either married or work as child labor to ensure their financial survival. After the NAP was passed in 2014, the restrictions were even lifted.

\subsection{Afghan socio-cultural barrier hinders female education}

The lack of female education can be attributed to socio-cultural factors such as early marriages, domestic responsibility and, above all, their socially constructed, conservative belittling of female education compared to male education. However, some of the refugees named the long distance between home and school and thus protection as a basic problem. While others also cite the lack of opportunities for refugee children to obtain secondary and higher education, especially after the 8th grade, this is also one of the reasons why most of the refugee girls hardly pass the 6th grade and continue to study. Likewise, the poor quality of education in refugee villages compared to formal Pakistani schools has significant consequences for the inadequate education of refugee children in Pakistan (UNHCR, 2018a).

\subsection{Miscellaneous Problems}

According to various reports by UNHCR and survey respondents, other challenges for Afghan refugees in general and children in particular are poor supervisory mechanisms, inadequate pay, unskilled staff and teachers, and lack of resources and educational infrastructure as the major challenges in their mission to provide access to refugee children Facilitate education.

\section{Conclusion and Recommendations}

In order to optimize the advice on education and other relevant refugee problems, working groups should first be formed at the provincial level, made up of refugee students, competent authorities from NGOs and INGOs, and government representatives from the social and educational sectors. These working groups are intended to complement the coordinative framework of the government-led SDGs at the provincial level, in which refugees are not represented, and will therefore develop a comprehensive mechanism that includes all actors.

Second, because of their importance for the education of Afghan refugee children, UNHCR and the government should sign a letter of intent with other organizations such as UNICEF, ILO, UNESCO, the Provincial Education Departments (PEDs), the Ministry of Education (MoE) and. sign Education Management and Information System (EMIS) to develop strategy to expand refugee access to Pakistani schools by abolishing the parallel education system. In addition, highly effective models from UNICEF, UNESCO and ILO can be adopted to improve the quality and durability of existing educational arrangements and programs for refugees, such as child-friendly schools.

Third, joint educational mechanisms should be developed at the provincial level to facilitate teacher training, capacity and professional skills, pay and retention; joint monitoring and the supervisory system should be used to improve quality education for the Afghan refugees. For such a control mechanism, the Afghan consulate should be considered as the 
competent body in refugee education. Create incentives for the education of Afghan refugees by adapting the curriculum to the Afghan counterpart.

Fourth, community-based schooling provides education to large numbers of refugee children, especially female students. Therefore, the quality and minimum standard of this community-based schooling should be improved by these agencies. In this regard, communities that have taken such initiatives should be supported and provided with IT solutions and other means to improve the quality of education. For example UNHCR's support for various NGOs in providing tablets for students in the Punjab and KPK provinces.

Fifth, A common regime was to be developed with UNHCR Afghanistan to enable the return of Afghan refugee children directly to the Afghan school system without complications. Parents also consider school lessons in the Urdu / English medium to be inconvenient for the later continuation of education in Afghan schools with mostly Pashto and Darri languages. Therefore, these children have to repeat a year to compensate for the basic requirements of the Afghan school system. Therefore, both Pakistan and the Afghan government should bilaterally agree on a common language code and curriculum for the Afghan refugees as part of the regional overall solution strategy for Afghan refugees (SSAR) so that they do not spend a year in the framework of the Afghan school system.

As highlighted in the challenges, the poor quality of education, i.e. the lack of qualified teachers and training, in most Afghan private schools, community schools and schools in the refugee villages compared to Pakistani private schools does not cover basic requirements. Therefore, UNHCR should work with the Pakistani government to develop programs to invest and establish solid surveillance and oversight of schools in order to improve their quality to an acceptable standard (UNHCR, 2018a).

\section{References}

Ahmadullah. (2020 July, 11) Afghan Refugee and Children Education in Pakistan/Interviewer: D. A. Jahangir. Mashaal Radio, KP, Pakistan.

Arab News Pakistan. (2020). Pakistan releases Rs.1.5bn in grants for Afghan university students. Retrieved from https://www.arabnews.pk/node/1702561/pakistan

Berthon, P., Nairn, A., \& Money, A. (2003). Through the paradigm funnel: a conceptual tool for literature analysis. Marketing Education Review, 13(2), 55-66. doi:https://doi.org/10.1080/10528008.2003.11488830

Bretts, A., \& Eagleton-Pierce. (2005). Human Security. St. Antony's College, University of Oxford, 5-10.

Bryman, A. (2008). Social research methods (3rd ed.). New York: Oxford University Press.

Creswell, J. W. (2009). Research design: qualitative, quantitative, and mixed methods approaches. Retrieved from Los Angeles, USA:

Displacement Tracking Matrix (DTM). (2019). Flow Monitoring of Undocumented Afghan Migrants. Retrieved from Bangkok, Thailand: https://reliefweb.int/sites/reliefweb.int/files/resources/Pakistan\%20FM\%202018\%20Re port 0.pdf

Economic Survey. (2020). Pakistan's literacy rate. Retrieved from https://www.thenews.com.pk/latest/671198-economic-survey-reveals-pakistansliteracy-rate-increased-to-60

Haq, M. U. (1994). Human Development Report. Retrieved from https://ideas.repec.org/p/hdr/hdocpa/hdocpa-1994-11.html

Levy, Y., \& Ellis, T. J. (2006). A systems approach to conduct an effective literature review in support of information systems research. Informing Science, 9, 181-212.

Mahbub-ul-Haq. (1994). Reflections on human development. Human Development Report Office (HDRO), United Nations Development Programme. Retrieved from https://ideas.repec.org/p/hdr/hdocpa/hdocpa-1994-11.html

Marshall, C., \& Rossman, G. B. (1995). Designing Qualitative Research (2nd ed.). London: Sage publications.

National Assembly Pakistan. (2018). The Constitution of the Islamic Republic of Pakistan. Retrieved from http://www.na.gov.pk/uploads/documents/1549886415 632.pdf

National Assembly Secretariat. (2012, December, 24). An act to provide for free and compulsory education o all children of the age of five o sixteen years. The Gazette of 
Pakistan.

Retrieved

from

http://aserpakistan.org/document/learning resources/2017/Right-to-Education-

Provincial-Legistlation/Islamabad-Free-and-compulsory-Education-Act-2012.pdf

Patton, M. Q. (2002). Qualitative research and evaluation methods. Thousand Oaks. Sage Publications, 4.

Prof. Dr. Nasreen Ghufran. (2020, July, 8) Afghan Regufees/Interviewer: D. A. Jahangir. University of Peshawar, Peshawar, Pakistan.

Refugees Magazine. (1997). (Afghanistan : the unending crisis) - The biggest caseload in the world. $\quad$ Retrieved from https://www.unhcr.org/publications/refugeemag/3b680fbfc/refugees-magazine-issue108-afghanistan-unending-crisis-biggest-caseload.html

The Express Tribune. (2019, May, 25). Modernizing Madrassas: Pakistan's response to tackle extremism. Retrieved from https://tribune.com.pk/story/1980160/1-modernisingmadrassas-pakistans-response-tackle-extremism/

UNHCR. (2017a, December, 31). Mapping of Education Facilities and Refugee Enrollment in Main Refugee Hosting Areas and Refugee Villages in Pakistan. Retrieved from https://data2.unhcr.org/en/documents/download/62554

UNHCR. (2017b, November, 30). Pakistan: Voluntary Repatriation of Afghans from Pakistan. Retrieved from https://reliefweb.int/sites/reliefweb.int/files/resources/62450.pdf

UNHCR. (2018a, June). Refugee Education Strategy 2016-2018 Pakistan. Retrieved from https://www.unhcrpk.org/wp-content/uploads/2018/06/Pakistan-Education-Strategy2016-18.pdf

UNHCR. (2018b, October, 2). Solutions Strategy for Afghan Refugees. Retrieved from https://data2.unhcr.org/en/documents/download/66534

UNHCR. (2019, November, 30). Pakistan: Voluntary Repatriation of Afghans from Pakistan Update. Retrieved

from https://reliefweb.int/sites/reliefweb.int/files/resources/62450.pdf

UNHCR. (2020, February, 10). Refugee Education Strategy 2020-2022 Pakistan. Retrieved from https://data2.unhcr.org/en/documents/download/73890

UNHCR Pakistan. (2020, April, 1). Protection Trends (January - March 2020). Retrieved from https://reliefweb.int/sites/reliefweb.int/files/resources/75175.pdf

UNICEF. (2019, January, 24). World celebrates first International Day of Education. Retrieved from https://www.unicef.org/pakistan/press-releases/world-celebrates-firstinternational-day-education 